\title{
Article \\ The Role of Non-Bank Financials in the Formation of Long-Term Resources for Economic Growth in Russia
}

\author{
Elena Vladimirovna Travkina *D, Elena Petrovna Ternovskaya * and Alim Borisovich Fiapshev *D \\ Department of Banking and Financial Markets, Financial University under the Government of the Russian \\ Federation, 125167 Moscow, Russia \\ * Correspondence: EVTravkina@fa.ru (E.V.T.); EPTernovskaya@fa.ru (E.P.T.); ABFiapshev@fa.ru (A.B.F.)
}

\section{check for updates}

Citation: Travkina, Elena

Vladimirovna, Elena Petrovna

Ternovskaya, and Alim Borisovich

Fiapshev. 2022. The Role of

Non-Bank Financials in the

Formation of Long-Term Resources

for Economic Growth in Russia.

Economies 10: 23. https://doi.org/

10.3390/economies 10010023

Academic Editor: Alexey Mikhaylov

Received: 28 November 2021

Accepted: 27 December 2021

Published: 11 January 2022

Publisher's Note: MDPI stays neutral with regard to jurisdictional claims in published maps and institutional affiliations.

Copyright: () 2022 by the authors. Licensee MDPI, Basel, Switzerland. This article is an open access article distributed under the terms and conditions of the Creative Commons Attribution (CC BY) license (https:// creativecommons.org/licenses/by/ $4.0 /)$.

\begin{abstract}
The development of the activities of non-bank financial institutions that accumulate the resources of the national savings system on a long-term basis is seen as a factor in increasing investment in the Russian economy and its growth rates. When carrying out the study, we used general scientific methods, methods of structural, weigh, and dynamic analysis, and comparisons of performance indicators of non-bank financial institutions. Problems in the activities of organizations in the non-banking sector of the Russian financial market are predetermined by the parameters and trends in the development of the socio-economic situation in Russia, including insufficient efficiency of regulatory practices. The positive dynamics of the development of non-bank financial intermediaries is qualified as unstable; it is not supported by the solution of the structural and institutional problems of the Russian economy. In view of this, an increase in their role in the redistribution process is associated both with decisions of a more general order and with the improvement of the regulatory and supervisory practices implemented by the Bank of Russia. The solution to the identified problems in the development of the non-banking segment of the financial market should be aimed at turning it into an effective mechanism for capital formation to ensure economic growth.
\end{abstract}

Keywords: non-bank financial institutions; national savings system; financial intermediaries; financial market; investment activity

\section{Introduction}

The nature and pace of macroeconomic dynamics reinforce Russia's place as a lagging country, which requires an increase in investment activity on a sustainable and balanced basis, especially in sectors producing and adopting innovations, based on the efficient use of resources accumulated by the national savings system. At the same time, the share of gross savings in Russia's GDP has been 25-27\% for a long time, and the conversion ratio of savings into investments is insufficient for their implementation at significant volumes and now barely exceeds $60 \%$.

The reasons for this situation are predetermined by the nature of the socio-economic situation in the country, as well as by the continuing mistrust of Russian citizens towards the financial market and, above all, its non-banking segment. Thus, the main participants in the Russian savings market remain commercial banks, the share of deposits (attracted mainly for periods of no more than a year) of which reaches $67 \%$ of total savings, while, in the USA it is $14 \%$, in China $47 \%$, and in Germany $41 \%$ (Dubinsky Oleg 2021).

The easing of the monetary policy of the Bank of Russia, caused by its desire to stimulate the growth of the Russian economy and its support in the context of the COVID19 pandemic, provoked an outflow of funds from the banking system to other sectors of the financial market. However, by international standards, the investment activity of non-bank financial institutions remains insignificant. Until now, approximately a quarter of all citizens with bank deposits were not familiar with alternative investment products, and 69\% of depositors had never used such offers (Litvin 2019). 
At the same time, non-credit (non-bank) financial institutions (NFIs) attract funds from the population and non-financial organizations mainly on a long-term basis, using specific instruments and in conditions different from bank deposits. The experience of a significant number of countries has shown a significant dependence of macroeconomic dynamics on the rate of development of the non-banking sector of the financial market. The activities of the institutions of this sector are influenced by such specific features of the Russian economy as the presence of a significant share of the population with limited opportunities for making savings, as well as the sufficient instability of their resource base for investments. Given the variety of types of such intermediaries, this study considers the activities of only a few of them: non-state pension funds and mutual investment funds. Making up one of the segments of the structure of the national savings system, such institutions increase its role in solving the problems of ensuring sustainable economic growth. The problem of activating this role is acute in countries with emerging markets. Containing the potential for a positive and high impact on economic growth, the activities of non-bank financial institutions may be limited by a set of factors inherent to the countries of this group. Among these factors are the lack of development of market institutions, insufficient efficiency of the existing mechanisms for protecting the rights of investors, and a high degree of state participation in the economy, which narrows the area for possible private investments. The purpose of this work is to identify reserves for increasing their role in the accumulation of resources in the national savings system and the redistribution of these resources in order to ensure the sustainability of economic growth, based on an analysis of the current state and development trends of the sectors of non-state pension and mutual investment funds of the Russian financial market.

\section{Review of the Literature}

The beginning of active research to assess the dependence of economic growth on the level of development of the financial market and its individual segments was laid out in the work of Schumpeter (1911), which substantiated the role of the financial sector in realizing the long-term goals of economic development using financial instruments to stimulate innovation. At the time of the prevalence of Keynesian ideas, this position could not find a significant number of supporters. However, with the further expansion of the financial market towards the end of the 20th century, a stable and close relationship between its development and economic growth has been proven (King and Levine 1993), with the possibility of faster growth in countries with more developed financial systems (Levine 2005; Demirgüç-Kunt and Levine 2008). The emphasis was on non-banking sectors, and the impact of market-oriented specialization of the financial market on long-term development was noted. However, it was later shown that the influence of the financial market on economic growth and social development is not linear (Law and Singh 2014; Arcand et al. 2015; Sahay et al. 2015), and this relationship may weaken as the financial depth of the economy increases.

Thus, an increase in the volumes of bank loans and in the debt burden can lead to a slowdown in economic growth, especially in the regions (Mutalimov et al. 2021). Not only does the volume of financial market services become important, but also their distribution between its various segments (Demirgüç-Kunt and Levine 2008; De Gregorio and Guidotti 1995; Levine 2005; Dabla-Norris and Srivisal 2013), as the development of the economy and its financial sector and the needs of businesses and the population in terms of new financial instruments are increasing. At the same time, there is a growing need to manage the increasing risks and diversify sources of capital attraction when the consumer preferences of citizens change as markets develop.

Studies carried out on empirical material on a group of developing countries have proven the need for advanced development of the non-banking segment of the financial market (Mamonov et al. 2018). In developing economies, a greater cumulative result is provided by the development of independent pension funds, insurance and fund segments, and the activities of institutional investors, which is becoming typical for Russia as well. 
Thus, if, earlier (Stolbov 2008) a significant positive relationship between the financial depth of the economy and GDP growth was not found, although it was assumed that, as the financial market developed, it could become a factor in economic growth, then, in later studies, such a relationship was confirmed (Danilov et al. 2017).

At the same time, the composition of the group of emerging market countries is heterogeneous in terms of the state of the economy, investment dynamics, and the role of the segment of non-bank intermediaries in the national savings system (Zvonova 2015; Litvin 2019). While, in China, the attraction of household savings for investment is hampered by actively stimulated growth in consumption at the expense of these savings (Rogoff 2019), in Russia, this slowdown is mainly due to the non-economic circumstances that shape its investment climate.

An increase in the role of non-bank financial institutions in redistribution processes is associated today with an increase in the availability of the products created by them, which is caused by technological innovations. The development of channels for the remote promotion and purchase of financial products, indeed, contributes to an increase in their availability. Measures for the development of financial technologies that are being implemented and expected to be implemented are aimed at solving this problem. However, they do not eliminate the limitations associated with insufficient motivation to transfer savings to the stock segment of the market, uncertainty of economic prospects, and the state of the investment climate (Fiapshev and Afanasyeva 2021). At the same time, the import of technology into both the financial and real sectors of the economy for developing countries is an expensive strategy. Therefore, it is more acceptable for these countries to develop their own "absorption capacity" strategy in areas such as institutional structures and labor force qualifications (Phelps 2019). This underlines the importance of linking technological and institutional modernization processes.

A review of the literature on the problem stated in this work shows the important role of non-bank financial institutions in redistribution processes. At the same time, the possibilities of realizing the potential of these institutions in the interests of sustainable economic growth are predetermined not only by the level of development of the financial market, but also by the characteristics of the national economy in terms of the quality of market, legal and political institutions. The underestimation by researchers of the second dependence we have identified, as well as the peculiarities of the Russian economy, determined the choice of the direction of analysis and its empirical basis.

\section{Methodology}

The research methodology was based on the proven positive dependence of gross domestic product dynamics on the financial depth of the economy, identification of the place and role of non-banking segments selected for analysis, dynamic analysis of statistical data and the analytical developments of the Bank of Russia, and the results of scientific and expert research in the field of financial markets. The specificity of the problems of economic growth and financial development, and their conditioning by various, often difficult to formalize factors, required the use of such methods as synthesis, analysis, and deduction for research purposes. Historical, logistic and heuristic approaches were also used. Methods of statistical observation, grouping and comparative analysis were used as tools for quantitative analysis.

Non-bank financial institutions, as part of the national savings system, act as institutions competing for free money resources in the economy. The prospects for their development are determined by the possibilities of redistributing these resources on a long-term basis, which, on the one hand, increases the stability of the resource base for investment and, on the other hand, ensures that their clients receive higher incomes. Such opportunities create the conditions for economic growth, which has been confirmed by numerous studies. At the same time, the implementation of these opportunities in emerging market countries, including Russia, is hampered by the continuing high level of uncertainty in economic prospects in the context of macroeconomic instability and poor performance 
of the implemented regulatory practices. Factors of distrust in the financial market and protection of investors' rights manifest themselves in the same direction. These conditions reinforce the indifference of the financial market, in terms of its non-banking sector, to the impact on it by economic methods. New financial and technological solutions give impulse to the development of this sector, but not to such an extent as to ensure the growth of real and financial investments. In essence, the substantiation of the conditionality of the dynamics of the development of the non-banking sector of the Russian financial market by circumstances of a non-economic nature is based on the recognition of the insignificance of the factor of economic policy and the technological factor.

The grounds for such recognition are the fact that, during the period studied in this work, the Russian regulator has consistently softened the conditions of monetary policy, and there has also been an unprecedented technological leap in the development of the financial market. Taking into account these conditions, the aim of the work was to assess the state and development trends of the sectors of autonomous pension and mutual investment funds, to substantiate the most significant factors of their dynamics and to propose possible solutions.

\section{Results}

An important feature of non-state pension funds, which have been accumulating pension savings for almost 20 years, is that these funds are practically the only market resource for attracting domestic savings to the Russian economy. The sector of non-state pension funds is represented mainly by large funds that control over $70 \%$ of the accumulated funds. However, the share of assets of non-state pension funds in the GDP amounted to only $4.2 \%$ (Bank of Russia 2021a) by the end of 2020, while the same indicator in the OECD countries averaged $40 \%$.

The absolute indicators that characterize the coverage of Russian citizens by the activities of foundations also have not significantly grown (Figure 1).

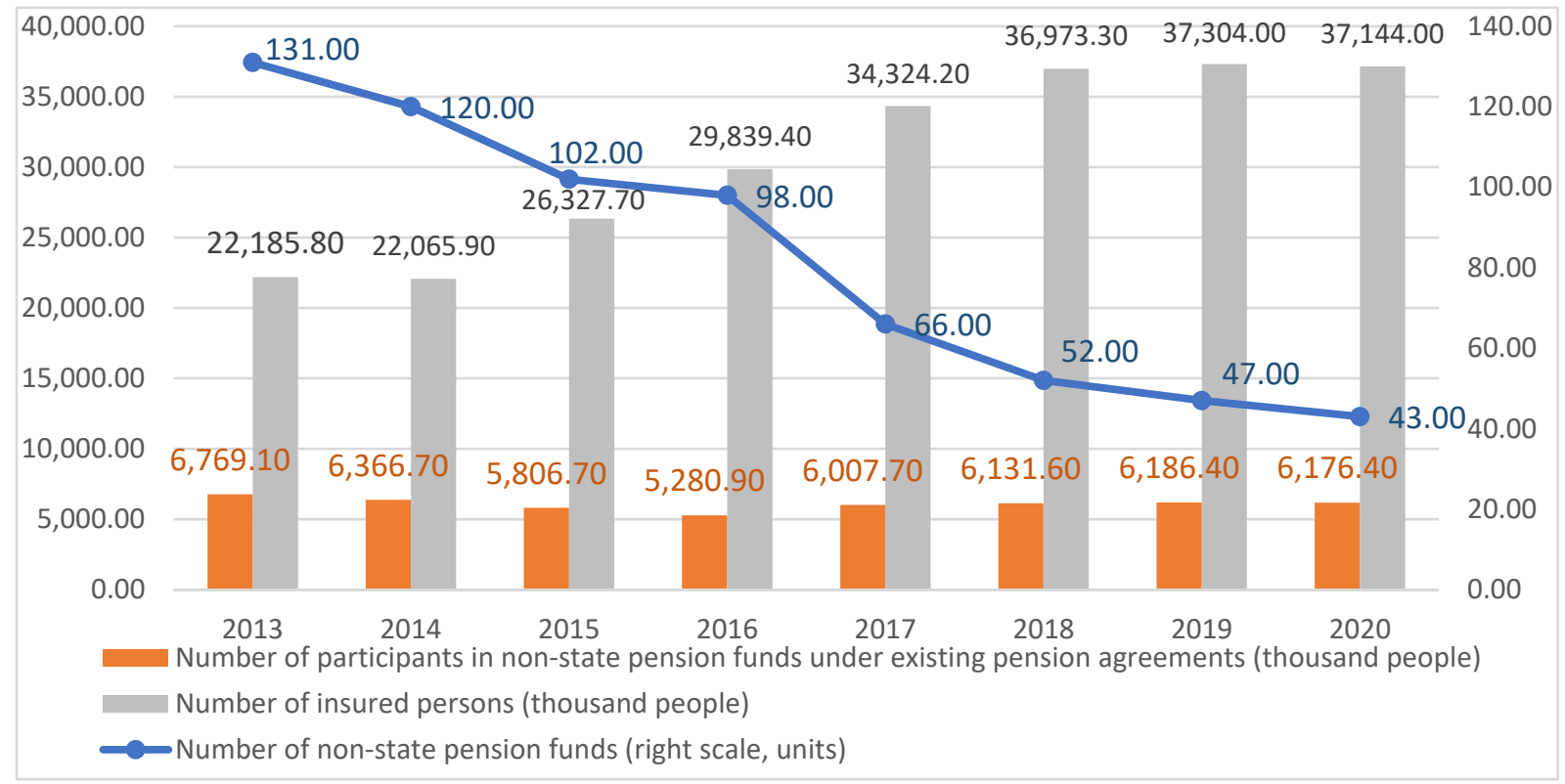

Figure 1. Selected quantitative indicators of the development of non-state pension funds. Source: (Bank of Russia 2021a).

At the same time, implementing a more aggressive and often more risky investment strategy, this sector gradually won more and more positions from the Pension Fund of Russia, which confirms the increase in the share of the non-state sector in the structure of pension savings (Figure 2). 


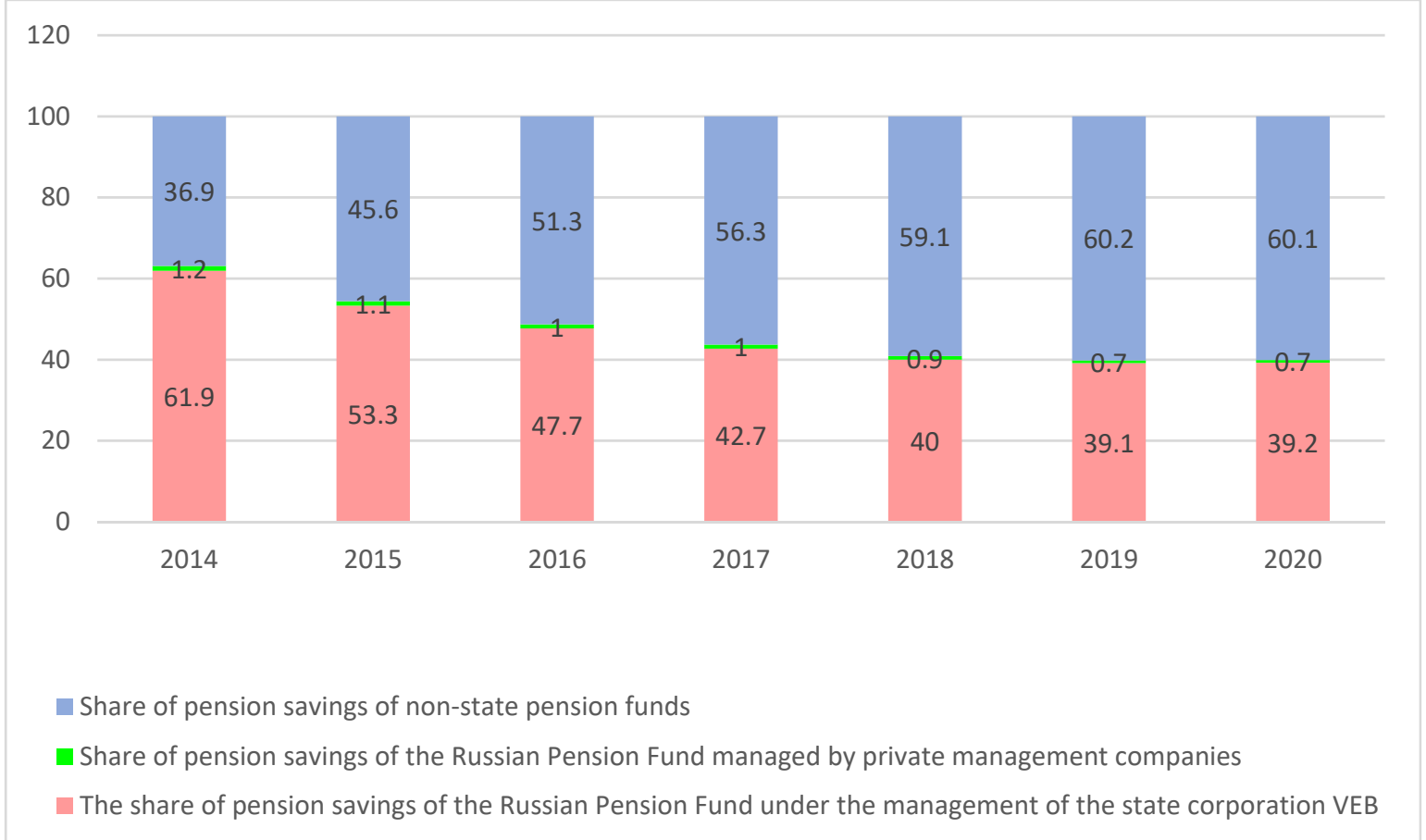

Figure 2. Dynamics of the structure of pension savings, at the end of the period,\%. Source: (Bank of Russia 2021a).

In the structure of the assets of non-state pension funds, the dominant positions are occupied by bonds of corporate issuers, although, during the COVID-19 pandemic, the growth of their share stopped due to the slow recovery of the corporate debt market amid growing yields on government debt securities. Prior to 2007, shares were also one of the investment priorities, but, subsequently, their share in the portfolio dropped noticeably, which was due to the increased risks associated with them, which many non-state pension funds could not afford.

The dynamics of profitability for all pension portfolios were uneven throughout the analyzed period of time. At the same time, the change in the indicators of the weighted average profitability of pension savings and reserves compensates for inflation losses not in all years and was much more attractive compared to the profitability of bank deposits and government pension savings, which also held back the development of this segment of the financial market (Figure 3).

Investments in corporate bonds also predominate in the structure of pension reserves; investments in government securities have grown significantly, with the share of stock falling by more than half. The weighted average yield from the placement of pension reserves during 2019 remained at a level lower than the yield on pension savings-8.2\% and $10.1 \%$, respectively - which was associated with a smaller share of debt instruments that showed good dynamics in this period in the investment portfolio pension reserves.

With the increasing role of the non-banking financial sector, the potential of these institutions is clearly underestimated, which was also facilitated by the state policy in the pension sphere. The confidence of a significant part of the population both in this policy and in non-state institutions has been significantly undermined. This can be confirmed by the data on the share of pension savings and reserves in the Russian GDP (Figure 4). 


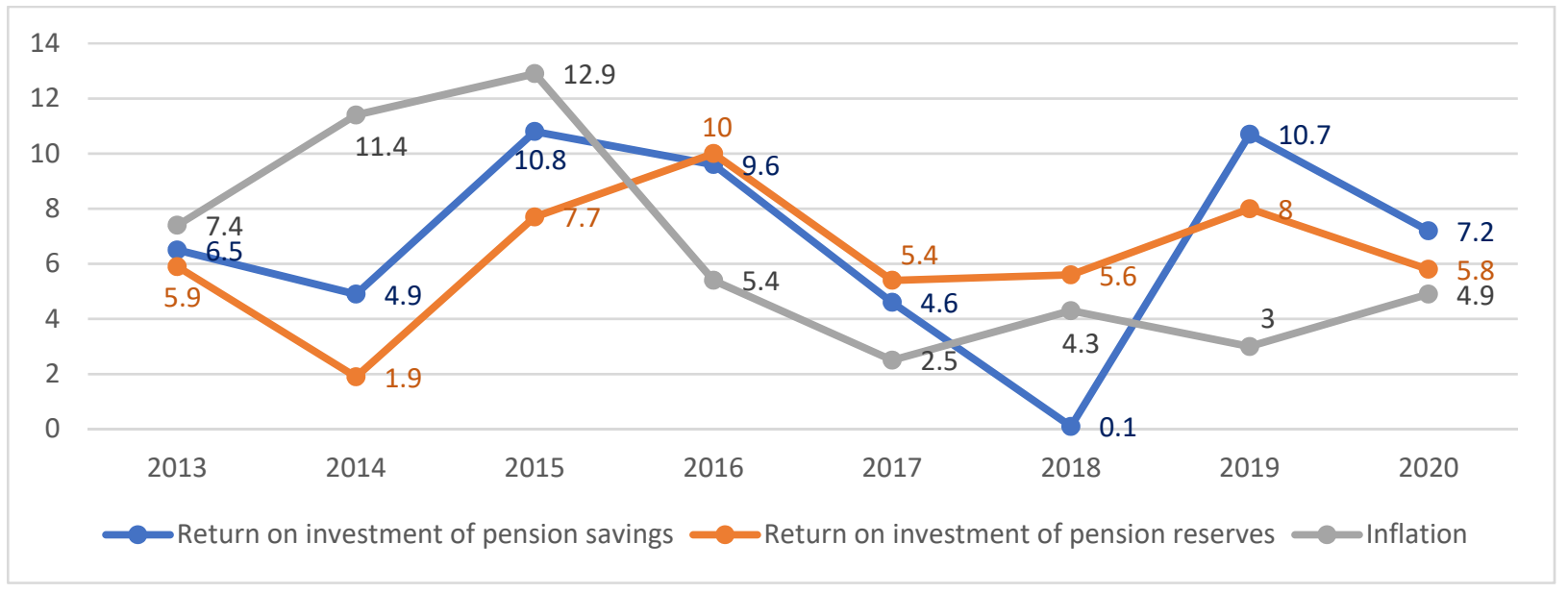

Figure 3. Weighted average return on investment of pension savings and pension reserves of non-state pension funds, \%. Source: (Bank of Russia 2021a).

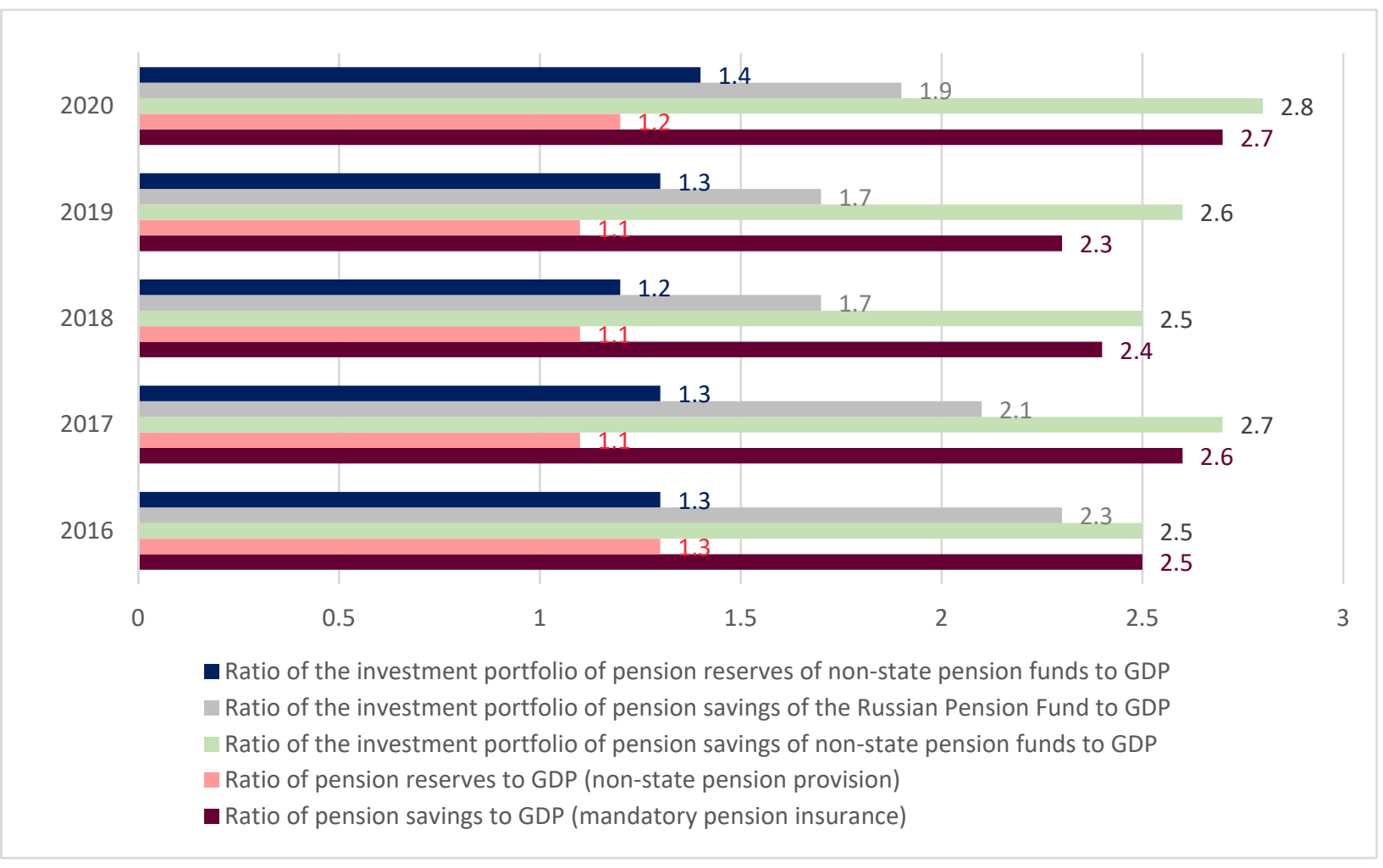

Figure 4. The ratio of the volume of pension savings and reserves and their investment portfolios to Russia's GDP, \%. Source: (Bank of Russia 2021a).

These indicators are significantly lower not only in comparison with developed countries, but also with a large number of emerging market countries, and against the background of insignificant GDP growth; in some years, they even declined.

A significant role in this is also played by the persistent unwillingness of a significant number of Russian citizens of active working age to plan their life prospects, taking into account the factor of distrust in non-bank investment products and the organizations selling them, especially in the context of persisting macroeconomic uncertainty and insufficiently effective state regulatory practices in the field of pension provision. This requires the implementation of serious measures in the field of economic policy, including in the field 
of providing Russian citizens with reliable guarantees to protect property rights, investor interests, and ensure the stability and predictability of regulatory and supervisory measures.

Mutual investment funds (UIFs) are another promising form of placing the population's savings, which can not only accumulate the savings of small investors, but also diversify them. The main features of Russian mutual funds include the following.

First, there is a significant dependence of the dynamics of attraction of savings in mutual funds on the state of financial markets, the macroeconomic situation, and the composition of mutual funds. Thus, the improvement of the situation in the financial markets and the development of online channels for the sale of investment instruments in conditions of falling in the profitability of bank deposits ensured high investor demand in 2019-2020, although a gradual increase in the key rate in 2021 may again increase the profitability of bank deposits and weaken interest in investments in mutual funds. Moreover, the emergence of such a new type of funds as exchange-traded funds (BPIF) led to a rapid increase in the number of their shareholders, with mostly small savings. As a result, the total number of mutual fund clients at the end of 2020 almost tripled and exceeded 2.6 million, and, only in the third quarter of 2021, the number of new clients increased by more than a million. However, at the end of the second quarter of 2021, out of the total number of individual clients in brokerage services, only approximately $40 \%$ of Russian citizens had non-empty accounts.

Second, there remains a significant differentiation of funds by categories of depositors, which is not typical for developed countries. This is confirmed by the data on the number of shareholders and the average amount of participants' investments. Thus, in 2020, an average of 2439 shareholders participated in one open-end investment fund, with a contribution of 596 thousand rubles; in one closed-end investment fund-10 shareholders and 107 million rubles; in exchange-traded funds-1913 shareholders and 62 thousand rubles. Given such a situation, it is still difficult to speak of a stable tendency for the formation of a mass stratum of collective investors.

As the experience of foreign countries shows, the main goal of creating collective investment funds is the formation of long-term sources of investment needs of the economy (as an important condition for ensuring economic growth) by creating a mass layer of individual investors. Thus, American mutual funds significantly exceed Russian openended mutual funds in terms of assets and have different specializations both in terms of company size and the type of debt securities. There are also differences in the structure of mutual funds: in the United States, the assets of mutual funds exceeded at the end of 2015 the assets of closed-end funds by almost 50 times (Investment Company Institute 2016).

Third, the structure of investments in various types of mutual funds and the degree of their diversification does not allow consideration of such funds as a significant source of financial resources for the modernization of the Russian economy, since investments in foreign securities began to occupy a significant share in the assets of funds (Table 1).

For example, $16 \%$ of the inflow of funds in the third quarter of 2020 came from a fund uniting a portfolio of 500 largest US companies, and approximately $11 \%$ from a fund investing investors' funds in shares of the 600 largest European companies, which was due to their high profitability and due to the lack of commissions to intermediaries when purchasing ETF shares through exchange-traded mutual funds. The sharp increase in the number of shareholders in closed-end unit investment funds (more than 5 times in 2020) was associated with the placement of shares of the fund, which also invests in IPOs of foreign issuers. This makes it possible to increase the profitability of the savings of Russian depositors, but, at the same time, it can enhance the withdrawal of funds from the country's securities market abroad, limiting the scale of investments for the Russian economy. 
Table 1. Dynamics of the share of the most significant investments in mutual fund assets.

\begin{tabular}{|c|c|c|c|c|c|}
\hline Investment Directions & III Quarter 2017 & III Quarter 2018 & III Quarter 2019 & III Quarter 2020 & III Quarter 2021 \\
\hline \multicolumn{6}{|c|}{ Open-end mutual funds } \\
\hline Shares of Russian issuers & 16.2 & 14.4 & 20.4 & 22.6 & 30.5 \\
\hline Bonds of Russian issuers & 39.2 & 48.6 & 45.6 & 39.0 & 24.5 \\
\hline Government securities & 15.6 & 9.8 & 6.7 & 7.8 & 8.0 \\
\hline Foreign securities & 19.1 & 19.3 & 20.9 & 27.0 & 30.9 \\
\hline \multicolumn{6}{|c|}{ Interval mutual funds } \\
\hline Shares of Russian issuers & 39.1 & 29.4 & 15.4 & 12.0 & 11.3 \\
\hline Bonds of Russian issuers & 12.6 & 7.3 & 11.3 & 12.0 & 11.0 \\
\hline Foreign securities & 21.9 & 31.0 & 42.8 & 54.0 & 44.2 \\
\hline \multicolumn{6}{|c|}{ Exchange-traded mutual funds } \\
\hline Shares of Russian issuers & $x$ & 93.8 & 14.0 & 15.0 & 17.3 \\
\hline Bonds of Russian issuers & $x$ & - & 17.2 & 13.2 & 19.8 \\
\hline Government securities & $x$ & - & 25.5 & 25.2 & 13.5 \\
\hline Foreign securities & $x$ & 5.3 & 41.8 & 44.0 & 38.8 \\
\hline
\end{tabular}

Source: (Bank of Russia 2021b).

Finally, the sectoral structure of mutual fund investments remains practically unchanged, with a low share of investment in high-tech sectors of the Russian economy. At the same time, according to international experts, "the development of productive capacities serves as a useful guide in setting investment priorities" to ensure sustainable economic growth in developing countries and countries with economies in transition (WIR 2021). The potential of mutual funds is also limited by the weak protection of depositors' funds, which is realized mainly by dividing them into qualified and unqualified investors, with corresponding restrictions on the composition of financial instruments. It is no coincidence that a number of experts are in favor of creating a system of guaranteeing the deposits of participants in open-ended mutual funds (Vishnever et al. 2019).

\section{Discussion}

The analysis revealed a set of urgent problems in the non-banking sector of the Russian financial market. Most of them are due to the gap between the development of individual sectors of this market and the entire national economy, as well as the unfavorable dynamics of the incomes of Russian citizens.

Structural and institutional problems of the Russian economy noticeably limit investment opportunities and narrow the range of relevant instruments (although the Bank of Russia as a whole has created conditions for financial investment in Russia). On the other hand, the formation and growth of savings are restrained by social problems, which is reflected not only in the resource base of pension and investment funds. Thus, the solution to the problems of development of organizations in the non-banking segment of the Russian financial market goes beyond the problems of this market and is also ensured by the implementation of measures in general in the field of economic policy. The necessary conditions for turning this segment into an effective mechanism for capital formation and increasing private savings should be:

- $\quad$ increasing public confidence in the financial market and in the state as a guarantor of the implementation of legislation;

- $\quad$ increasing the level of protection of the rights and legitimate interests of investors;

- development of a system of voluntary pension savings, including securing the ownership of pension savings for future retirees; 
- $\quad$ carrying out the privatization of state-owned enterprises and shareholdings, using mechanisms aimed at limiting the concentration of ownership and increasing competition;

- focus on advanced foreign practices to ensure transparency of information about financial instruments and products for making investment decisions.

The set of measures to enhance the activity of non-state pension and mutual investment funds can be divided into two groups. The first group consists of measures to create the necessary conditions external to the financial market, including:

1. Improvement of the state policy in the field of pension provision of citizens on the basis of ensuring its transparency, building a clear hierarchy of goals, and determining the time frame for their implementation;

2. Improving the investment climate and institutions, which is a condition for the effectiveness of measures to protect the interests of investors and the rights of consumers of financial services;

3. Reducing the share of the state in the economy in order to create the necessary conditions for enhancing its financial depth and competition.

Such external circumstances form the necessary conditions for the effective activity of these institutions, and can change the motives of the saving behavior of citizens with a focus more on long-term interests. The solution of these tasks can also be facilitated by measures already tested in international practice-in particular, the use of the capabilities of funds in corporate governance (stewardship), including through the mechanism of independent directors and their participation in programs of the privatization of state property.

In recent years, more and more funds have attached importance to such participation, developing management skills in the development of their own governance code, monitoring and evaluation of companies as investment objects, taking part in voting on the board of shareholders, contributing to the creation of added value over the long term, the integration of environmental, social and governance factors, as well as increasing the transparency of information and its more complete disclosure.

Today, domestic funds are limited in investing in certain instruments and therefore do not have enough capital to fully participate in corporate governance. In such conditions, funds should develop cooperation and delegation of a common representative to the board of directors in order to unite the efforts of minority shareholders in influencing the decisions of the invested company in order to increase the profitability and reliability of their investments.

In addition, the privatization of state property can significantly expand the financial market through new objects for long-term investment by funds, which, in turn, will allow them to increase their resources and attract new participants.

On the other hand, in order to finance the sustainable growth of the Russian economy, it is becoming urgent to expand the composition of the main products of mutual funds (Zvonova 2015), to stimulate the development of the corporate bond market (for example, by establishing the normative value of "such investments for mutual funds and other investors at the level of $8 \%$ assets" (Ushanov 2019)), the inclusion in the portfolios of mutual funds-for example, securities of the Industrial Development Fund, designed to provide financial support for investment projects in the real sector of the Russian economyas well as mortgage-backed bonds, the share of which, in 2020, was, in mutual funds for qualified and unqualified investors, only $0.6 \%$ and $1.7 \%$, respectively. Their share could be increased by the issue of mortgage securities for such a new direction of mortgage lending, which is especially in demand in the regions, such as rural mortgages (Ternovskaya 2020). For mutual funds including such instruments in their portfolio, it is possible to envisage regulatory relaxation from the Bank of Russia.

The level of protection of participants' savings can be increased on the basis of expanding the investments of mutual funds in sectors of the economy focused primarily on meeting domestic demand, as well as the formation of an insurance fund from the contributions of management companies. The amount of compensation for losses incurred 
under unfavorable macroeconomic conditions could be established as a certain share of the invested funds or a fixed amount (for example, at a level that is a multiple of the subsistence minimum, but not more than a certain amount).

The proposed solutions presuppose an emphasis on institutional reforms and increasing the efficiency of interim measures of the already implemented directions of development of this market sector. We do not exclude the importance of easing the conditions of monetary policy with a steady achievement of the declared price target, as well as the need for further digital modernization of the processes being implemented in the financial market. However, these measures only form the necessary, but not sufficient, conditions for the transformation of the financial market into a factor of positive, sustainable macroeconomic and social dynamics. This is confirmed by the pronounced gap that exists today between financial development, which is provided mainly by the banking system, and the state of the real sector of the economy, the social sphere. Elimination of this dichotomy seems to be possible on the basis of a more active role in the financial development of organizations that accumulate resources on a long-term basis, which in turn requires political, institutional, and instrumental solutions in combination with a balanced economic policy.

In addition, the social effect of the development of the analyzed sector of the financial market should not be underestimated. From a strategic perspective, it lays the foundations for reducing social inequality and forms the appropriate guarantees, which is very important, given the extremely contradictory and often ineffective nature of the decisions made by the Russian authorities in the pension sector over the past two decades.

\section{Conclusions}

In Russia, in recent years, there has been unprecedented growth in the non-banking segment of the financial market, mainly caused by the easing of the monetary policy of the Bank of Russia and the infrastructure created by the regulator for these investments, which increased the interest of savings holders in this segment.

However, this effect cannot be considered sustainable, since significant restrictions continue to operate, formed by an unfavorable socio-economic background, the potential for the introduction of new sanctions against the Russian economy, and indecision of its structural, institutional, and management problems. Therefore, most of the decisions reach the level of the entire Russian economy, which does not exclude the need to improve the efficiency of the Bank of Russia in relation to organizations in the non-banking segment of the financial market.

A particular problem is the continuing lack of trust among citizens and businesses in organizations that sell investment products and attract funds for a long time, as well as the degradation of the social situation, in which new savings are not created, but existing ones are "eroded".

The problems of extending state guarantees to the insurance and pension contributions of citizens, deposits of shareholders of cooperatives (by analogy with the reimbursement of deposits), improving the taxation of income from the investment of insurance and pension reserves, increasing the effectiveness of state control, and supporting the activities of non-bank financial intermediaries remain relevant. The proposed measures can not only alleviate the severity of the current crisis, but also lay the foundation for sustainable development in the long term.

Author Contributions: Conceptualization, methodology, formal analysis, investigation writingreview and editing, E.V.T., E.P.T., A.B.F.; project administration, E.V.T. All authors have read and agreed to the published version of the manuscript.

Funding: This research received no external funding.

Institutional Review Board Statement: Not applicable.

Conflicts of Interest: The authors declare no conflict of interest. 


\section{References}

Arcand, Jean-Louis, Enrico Berkes, and Ugo Panizza. 2015. Too Much Finance? Journal of Economic Growth 20: 105-48. [CrossRef] Bank of Russia. 2021a. Review of Key Indicators of Non-State Pension Funds. Information and Analytical Material. Moscow: Bank of Russia, Available online: https:/ / www.cbr.ru/Collection/Collection/File/31591/rewiew_npf_20Q3.pdf (accessed on 15 April 2021).

Bank of Russia. 2021b. Review of Key Indicators of Mutual and Joint-Stock Investment Funds. Moscow: Bank of Russia, Available online: https:/ / cbr.ru/Collection/Collection/File/31574/rewiew_pif_aif_21Q3.pdf (accessed on 10 October 2021).

Dabla-Norris, Era, and Narapong Srivisal. 2013. Revisiting the Link between Finance and Macroeconomic Volatility. IMF Working Paper Vol. 13/29. Washington, DC: IMF.

Danilov, Yu. A., Oleg Vitalievich Buklemishev, and Alexander Evgenievich Abramov. 2017. On the necessity of reforming financial markets and the non-banking financial sector. Economic Issues, 28-50. [CrossRef]

De Gregorio, Jose, and Pablo Emilio Guidotti. 1995. Financial Development and Economic Growth. World Development 23: 433-48. [CrossRef]

Demirgüç-Kunt, Asli, and Ross Levine. 2008. Finance, Financial Sector Policies, and Long Run Growth. Spence Growth Commission Background Paper No 11. Washington, DC: World Bank.

Dubinsky Oleg. 2021. How Money Is Kept in Different Countries. Why Russians in 2020 Postponed 2 Times More. Market Overview 13 March. Oleg Dubinsky. Available online: https:/ / smart-lab.ru///blog/683161.php (accessed on 9 April 2021).

Fiapshev, Alim Borisovich, and Oksana Nikolaevna Afanasyeva. 2021. Digitalization as a Factor of Development of Russia's Banking System. In Meta-Scientific Study of Artificial Intelligence. Charlotte: IAP (Information Age Publishing, INC), pp. 461-469.

Investment Company Institute. 2016. Profile of Mutual Fund Shareholders, 2015. ICI Research Report. Washington, DC: Investment Company Institute, Available online: http:/ / www.ici.org/pdf/rpt_16_profiles.pdf (accessed on 27 November 2021).

King, Robert G., and Ross Levine. 1993. Finance and Growth: Schumpeter Might Be Right. The Quarterly Journal of Economics 108: 717-37. [CrossRef]

Law, Siong Hook, and Nirvikar Singh. 2014. Does Too Much Finance Harm Economic Growth? Journal of Banking and Finance 41: 36-44. [CrossRef]

Levine, Ross. 2005. Finance and Growth: Theory and Evidence. In Handbook of Economic Growth. Edited by Philippe Aghion and Steven Durlauf. Örebro: Örebro University Business School, pp. 865-934.

Litvin, Valeria Viktorovna. 2019. National Savings System: Research Methodology, Patterns and Development Prospects. Moscow: RUSAYNS.

Mamonov, Michael, Renat Akhmetov, Vera Pankova, Oleg Solntsev, Anna Pestova, and Artem Deshko. 2018. Identification of Financial Sector Optimal Depth and Structure from the Perspective of Economic Growth, Macroeconomic and Financial Stability. Russian Journal of Money and Finance. Money and Credit 77: 89-123. [CrossRef]

Mutalimov, Verdi, Irina Kovaleva, Alexander Mikhaylov, and Daria Stepanova. 2021. Assessing regional growth of small business in Russia. Entrepreneurial Business and Economics Review 9: 119-33. [CrossRef]

Phelps, Edmund S. 2019. The Three Revolutions Economics Needs. Project Syndicate, January 23. Available online: https:/ /www.projectsyndicate.org/commentary/economics-must-change-in-three-ways-by-edmund-s--phelps-2019-01(accessed on 27 November 2021).

Rogoff, Kenneth. 2019. Risks to the Global Economy in 2019. Project Syndicate, January 11. Available online: https://www.projectsyndicate.org/commentary/global-economy-main-risks-in-2019-by-kenneth-rogoff-2019-01(accessed on 27 November 2021).

Sahay, Ratna, Martin Cihak, Papa N'Diaye, Adolfo Barajas, Diana B. Ayala Pena, Ran Bi, Yuan Gao, Annette J. Kyobe, Lam Nguyen, Christian Saborowski, and et al. 2015. Rethinking Financial Deepening: Stability and Growth in Emerging Markets. IMF Staf Discussion Note SDN. No 8. Washington, DC: IMF.

Schumpeter, Joseph A. 1911. A Theory of Economic Development. Cambridge: Harvard University Press.

Stolbov, Michael. 2008. The influence of the financial market on economic growth in Russia. Economy of the XXI Century, 65-75.

Ternovskaya, Elena Petrovna. 2020. Russian mutual funds as a form of collective investment of savings. Economy Business Banks 47: 9-20.

Ushanov, Alexander Evgenievich. 2019. On the development of the corporate bond market. Azimuth of scientific Research: Economics and Management 8: 353-56. [CrossRef]

Vishnever, Vadim Yakovlevich, Elena Sergeevna Nedorezova, and Vyacheslav Mikhailovich Kuskov. 2019. Trends and prospects for the development of mutual investment funds in the system of collective investment. Economic Sciences 9: 19-24.

WIR. 2021. World Investment Report: Investing in Sustainable Recovery//UNCTAD//[Electronic Resource]. Available online: https:/ / unctad.org/system/files/official-document/wir2021_overview_ru.pdf (accessed on 27 November 2021).

Zvonova, Elena Anatolyevna. 2015. Features of accumulation of savings of the population on the Russian stock market. Economics Taxes Right, 40-48. 